\title{
XXXIX. History of the art of dyeing, from the earliest ages
}

\section{J.N. Bischoff}

To cite this article: J.N. Bischoff (1801) XXXIX. History of the art of dyeing, from the earliest ages, Philosophical Magazine Series 1, 9:36, 302-315, DOI: 10.1080/14786440108562704

To link to this article: http://dx.doi.org/10.1080/14786440108562704

曲 Published online: 25 Jan 2010.

Submit your article to this journal $\asymp$

Џ Article views: 2

Q View related articles $\sqsubset$ 
3. It has every advantage which may be attributed to Boulton and Watt's engines, by condenfing out of the receiver, either in the penftock or at the level of the water.

4. Another very great advantage is, that the water in the upper part of the pipe adjoining the receiver acquires a heat, by its being in frequent contact with the fteam, very nearly equal to that of boiling water ; hence the receiver is always kept uniformly hot, as in the cafe of Boulton and Watt's engines:

5. A very fmall ftream of water is fufficient to fupply this engine, (even where there is no fall,) for all the water raifed by it is returned into the refervoir $\mathrm{HHH}$.

From the foregoing reafons it manifeftly appears, that no kind of fteam-engine is fo well adapted to give rotatory motion to machinery of every kind as this. Its form is fimple, and the materials of which it is compofed are cheap; the power is more than equal to any other machine of the kind, becaufe there is no deduction to be made for friction, excep̣t on account of turning the cocks, which is but trifling.

Its great utility is therefore evident in fupplying water for every kind of work performed by a water-wheel, fuch as grift-mills, faw-mills, blaft-furnăces, forges, \&c.

XXXIX. Hiflory of the Art of Dyeing, from the earlieft Ages, By J. N. Bischoff.

[Concluded from Page 21\%]

$\mathrm{I}_{\mathrm{F}}$

the hiftory of dyeing in the former period appears im * perfect and dêficient, it will be found ftill more fo in the prefent one, which contains an account of the ftate of it in the weft after the fifth century. And, indeed, it needs excite no wonder if great filence prevails refpecting an art at that time fo little valued, as we are left in much uncertainty in regard to many other things of great importance. Thîs much, however, we know, that during the general banifhment of the fciences, arts, and manufaetures from the weft, in confequence of the incurfions inceffantly made by multitudes of barbarians and warlike nations, that of dyeing was 
annong the number. It cannot, however, be denied that there occur traces of this art being practifed in fome of the Italian monafteries and other places. But the articles dyed were of little importance, being chiefly brown or black linen, or Rins, fo that the art in this ftate fcarcely deferves the name of dyeing.

Of this art Muratori gives only one inftance in the eighth century from an old manufcript preferved in a monaftery *, which, on account of the barbarous Latin in which it is written, and the illegible paffages in it, is fcarcely. intelligible. This, however, is fufficient to give us an idea of the ftate of dyeing in the weft at that period; but, if more thould be thought neceffary, I have no dopbt that thexe are documents in old monafteries to fatisfy the curiofity of thofe who wifh for further information on the fubject.

It is certain, indeed, that the art of giving cloth and other articles a beautiful dye, had difappeared from the weft in the fifth century, and was to be found only in the eaft t. Buts even there little attention was paid to impsovement ond new difcoveries, as dyers were fatisfied with thofe eqlontrs which had been long ufual, and which, in a great meafure, have been already defcribed.

The Greeks and Saracens were for a long time the exclufive poffeffors of this art, and furnifhed the weit with dyed ftuffs, and particularly purple, which, aceording to the account of the female Greek writer mentioned in the former part of this paper, was prepared there of a beautiful colour in the in th century. The public tafte, howeyer, was at length changed, and people began to fet as great value on the fcarlet then dyed as upon purple, and at length to prefer it; and on this account, in the 12th century, the art of dyeing purple in the eaft was entirely forgotten $\ddagger$.

* Muratori Differtat. de Artibus Italicor. poft Inclinationem-Romani Imperii; in his Antiquitat. Iralic. vol. ii. diff. 24. p. $3^{67}$.

$f$ It is not improbable, therefore, that Attila brought with him that purple cloth with which his throne, according to an old poet, was hang round during a great feftival. See the Deutfcbes Mufeum for Jan, i, 80 , p. 69.

* Muratori Differtat. de Textrina et Veftibus Sxeulorum Rudium ; in vol. ji. Antiquitat, Ital. diff. 25, p. 415 .

Though, 
Though, in confequence of the erufades in the IIth arid following centuries, this art began to be revived in the weft, as the Chriftian princes who went on thefe expeditions brought back' with them a great many Greek artifts, dyeing had betn fo little improved, that; according to the teftimony of an old Englith poet, Gualfred de Winefauf, who wrote a fatire about the year 1202 , the Romans at that period obtained their fcarlet from Greece *. 'Soon after, however, the Italians, and particularly the Venetians, made confiderable progrefs in this art: for, as the crufaders were conveyed to the Holy Land and brought back from it chiefly in Italian fhips, the Italians had the beft opportunities either of learning the art of dyeing beautiful colours themfelves, or of carrying back expert dyers, whom they muft have found very neceffary to their manufactures, which were then beginning to increafe t. About this period, therefore; we find here and there traces of new dye-materials, or, at leaft, materials not before meritioned. Thus; a charter of the year I194, which is a contract between the inhabitants of Bologna and thofe of Ferrara refpecting certain duties, fpeaks of Brafil grains (grana de Brafile) and of indigo as articles which were obliged to pay duty at Bologna $f$.

In regard to the indigo here mentioned, I can hardly believe that we are to underftand by it our dye-ftuff of the fame name; as a more modern writer, Plictho, whom I thall mention hereafter, was unacquainted with our indigo. It is much more probable that what is here meant is the fubftance which occurs in Pliny under the name of indicum, and which was merely a paint $\S$. In the like manner, a paint was known in Germany called $\epsilon$ dicb before real indigo was known; which, as we are told by Crolach in his defcription

* Muratori ut fupra.

+ So early as the year $133^{8}$ there were in Florence 200 cloth manufactories, which manufactured annually from 70 to 80,000 pieces of cloth, valued at 1,200,000 florins.-See Della Decima, tom. ii. p. 3. Fez. 4. c. 9.

$¥$ Muratori Difiert. de Mercatibus et Mercatura Sæculorum Rudium, tom. it. Antiquitat. diff. 30. p.898.

$\S$ Plin. lib. xxxv, cap, 6. He defcribes this colour as a fcum which adhered to certain reeds. 
of woad, taken from an oid author, was made of what the acers at prefent call the flower of the woad.

But the Brafilian grains and Brafilian wood are mentioned in more old charters, as, for example, of the years 1798 and 1306, under the name of braxilis. This wood, therefore, may have not taken its name from the country called Brafil; but the latter rather got its name from the wood, which was found there in abundance, and in the language of the country was called ibirapitanga. In my opinion the name brafilis comes from bragia, in French braife, a burning coal, which it may have obtained both from its colour and its having the property of communicating it to others. But, as I thall have an opportunity hereafter of enlarging further on this dye-Ituff, I thall proceed to another difcovery of that period, male by a Florentine, viz. that of dyeing by orchilla-weed.

A Florentine merchant, who about the year I 300 traded in the Levant, happening to make water on a rock, obferved that the green colour of the mofs which grew on it, and on which the urine accidentally fell, was changed to a beautiful blueifh colour. Reflecting a little further on this circumfince, be found, after feverit experinents, that when mixed with urine and other things it communicated to cloth a columbine colour. This procels he long kept as a fecret, and acquired by it a great deal of money. The invention at that period was fo profitable to the Florentines, and excited fo much wonder, that the family of the inventor, which fill exilts in Italy, were called Rucellai, from the name of the mofs, which in Spanifh is diflinguifled by the appellation of erciglich, and the dye made from it is called orchilla *.

After this period the manufactmes in Italy increafed fo that the attention of the different governments was particularly directed to the art of dyeing. In the year 1429 there were publithed ai Venice fome regulations refpecting dyeing (Moricgala doll' Arte dei Tintor), in which certain precepts were given for dycing, and according to which dyers were to exercife their art $\uparrow$. Thele regulations were renewed in the year I510, with a great many improvements. One John

"Domenico Mani Commentar. de Florentinorum Inventis, c. 20.

+ Zavon Lettere dell' Agriculcura, \&c. tom. iii, p. 2. lett, 6 .

Yox. IX. 
Ventura Rofetti, however, finding thefe precepts too imperfect, made a tour, at confiderable expenfe, through Italy and ather countries to procure information refpecting the art of dyeing, and on his return wrote, under the affumed name of Plictho, a book on it; the firft, perhaps, that ever appeared on this fubject, and which undoubtedly laid the firt foundation for the improvement in this art which afterwards took place*.

The title of this work, exceedingly fcarce even in Italy, an original edition of which is preferved in the royal library at Göttingen, is as follows :-Plictho's Art of Dycing; which teaches how to give to Cloth, Linen, Cotton, and Silk, real and beautiful as well as falfe and common Dyes. Venice 1548.4 to. The whole work is divided into three fections; the firft of which treats on the dyeing of wool, linen, cotton, chintz, \&c. the fecond on the dyeing of filk, and the third on the dyeing of fkins.

However difficult it may have been at that time to write upon this art, Plictho, in the preface to his book, where he fpeaks of the period in which he lived with a candour peculiar to himfelf, fays: "I will therefore, dear reader, no longer keep back thefe three works. I have exerted myfelf with all my powers by day and by night for months and years, with danger and lofs, at the expenfe of much hard labour, and as far as my poor circumfances would permit, to improve this important art, for fixteen years pait, and with God's help to bring it to a proper ftate." - This author was not acquainted either with indigo or cochineal ; but he fpeaks of brafil wood, which he calls verzino, a name ftill given to

"Beckmann's Technology, p. 60.

t The Italian trite is. Plsetho de larthe de Tentori, che infegna Tenger Panni, Telle, Banbafi et Sede, fi per larthe magiore come per la commune. Y:negia $\mathrm{I}_{5} 4^{\mathrm{R}}$. 4to. The real name of the author, as I have already obfeived, was John Ventura Roferti; he was overfeer of the arfenal of Venice, as he gives us to underftand himfelf in the end of his book. This wo $k$ has been ranlit ${ }^{\prime}$ ed into French under the following title: Suite $d u$ Teinturier parfast, ou l'Art de Teindre les Laines, Soyes, Fils, Peaux, Poils, Plumes, \&ic. comme il fe pratique à Venize, Genes, Florence, ct dans tout le Levant; et la Maniere de paffer en Chamois toute Sorte de Pcaux, traduite de l'Italien. Ponis 1916. 
it in Italy, and from which the word brafizis, as appears, has been derived. Though Hellot and others defpife this work as a wretched collection of recipes, we cannot deny the author the merit of having firft opened the way to improve the art of dyeing; of having brought it into high reputation; and, in particular, of having excited towards it the attention of foreign nations.

For about two hundred years before, the Italians, and particularly the Venetians, had a monopoly of dyeing, and procured large fums by it from neighbouring nations, who made no exertions to practife the art themfelves; for ftatefmen and men of letters did not think it worth their while to give themfelves any trouble about it, and from dyers no change whatever was to be expeeted. But Plictho was the firt who exhibited this art in its full luftre, and excited the French, Englifh; and Germans, to apply in earneft, in their different countries, to the improving fo ufeful and extenfive a branch of manufacture.

In France fome progrefs towards this object had been already made. One Giles Gobelin, who had learned from a German the art of dyeing fcarlet, endeavoured to eitablith it in that country, and for this purpofe erected a dye-houfe, in the fuburbs of Paris, on a fmall ftream called the Bievre, the water of which was found peculiarly favourable to that colour. This undertaking was at firft confidered to be a work of fo much difficulty that no one believed he would be able to complete it, and for that reafon this dye-houfe was called La Folie Gobelin, that is, Gobelin's Folly *.

Gobelin, however, continued his bufinefs, and fcarlet dyed after his manner is fitll called Gobelin's fcarlet, and a building in which tapeftry is now made is ftill diftinguithed by his name $\uparrow$. But dyeing in general continued in a very imperfect

ftate

- See Hifrire de I'Acatemie Royale des Sciences de Betlin Sor 1967, p.67.

+ Pcople at that time were fo Igrorant in matters of this kind that they could not believe that Gobclin performed what he did without fupernatural affiftance. They invented, therefore, the following, ftory :-Gobelin is faid to have entered into a compad with the devil, who was to teach him the art of dyeing fcarlet; and, having learned it, he gained by it a great deal of money. When the term of the compaet, bowever, was 
ftate till Colbert, the great minilier of Louis XIV. in the year 1669 , undertook to pay attention to its inprovement. With this view he examined the eftablifhment and defects of the Firnch dyeing, and a M. d'Albo, at his defire, compofed a fet of regulations refpecting dyeing, which were printed and publithed at Paris in the years 1669 and 1672 .

The introduction to this book contains a proof of Collort's mode of thinking in regard to this art:-" If the filk, woollen, and liuen manufactories," fays he, "are thofe which contribute mont to the lupport and advancement of trade and commerce, dyeing, which fupplies that variety of colours by which the molt beautiful things in nature are imitated and reprefented, may be confidered as the foul of it, without which the body would be animated only by fecble life. Wool and filk in their natural colours, formerly raw articles of little value, now find fale in the country, when they have received front dyeing thofe attractions which render them valuable and agrecable to the moft favage nations."

The treatile itfelf is divided into twelve chapters: the firft treats on the five principal colours, and the preparation of the articles before they are dycd; the fecond, of the application of the dye-ftuffs; the third, of the different thades of the above

nearly terminated, as Gobelin was palfing through the court-yard with a light in his hand, the devil came tix fetch him awdy. Gobelin begged for a refpite, but the evil fprrit would not grant it. Gobelin at idt requefted that the devil would wait till the bit of candle in his hand was burnt out. 'This being granted, Gobelin inmedrately threw it into a well and pufhed the devil in after it The devil thus outwitted was exceedingly angrs: but Gobelin had tume to get a gudrd of ecclefiaftics, who fecured him frum limilar attacks in future - See Zanon as above, fixth book, third Jetter.

* The title is: Infrutution générate pow la Teinture des Laines et $M h_{\text {, }}$ nufactures de Laine de toutes Coulewrs, at pour la Culture des Diogues on Ingrediens quion $y$ employe: a Paris 1672. szmo. This work was reprinted in the lalt century under the fullowing title: Le Teinturier parfant: ou Infruation notivelle et gététule pou la Teinture des Laines et Manufarture de Lane. ale touses Couleurs, ct porer la Culture des Drogues ou Ingr:diens quion.y cmplove: à Leyde, chez. Theod. Hdach, 1708. bro. The laft edition appeared in 1726 in two parts. There is alfo a German edition by Paul James Marperger, with the title Ars Tinctoria furdamentalis. Refpedting this book fee Minoires concernant les Arts et les Sciences for the year 1673 ; and the Leipz. Sammlam $z^{2}$, vol. iii. for 1746 , p. "1o13. 
colours; the fourth, of compound colours; the fifth, of the divifion of colours into fine colours (teinturiers en bon ieint) and common colours (teinturiers en petit teint ${ }^{*}$ ); the fixth, of the dyers' marks, with which they mark the articles they dye in both the above ways; the feventh contains a catalogue of the dye-ftuffs permitted to be ufed for dyeing the fine and common colours; the eighth gives an account of the reafons why certain kinds of dye-ftuffs are prohibited; the nintl treats entirely on dyeing black; the tenth, of the ground and bath proper for each colour; the eleventh treats on the dyeing of linen and hats; and the twelfth recommends the ufe and cultivation of indigenous dye-ftuffs, a lift of which is given.

That thefe regulations might be properly obferved, certain infpectors and commiffioners were not only appointed to vifit the dye-houfes and repofitories of the merchants, but orders were afterwards given to a member of the Academy of Sciences to make experiments for improving and beautifying different dyes, and to lay the refult of his difcoveries before the academy, which were afterwards to be publinhed for the practical ufe of dyers.

The great advantage of this eftablifhment may be eafily conceived from the preference given to the French dyes; and the works which Du Fay, Hellot, and others, have written on this fubject, and with which every dyer ought to be acquainted.

Abont this time the dye-ftuffs brought to Europe from the newly difcovered countries, but efpecially indigo and cochineal, began to be employed with great advantage. The Netherlanders, in particular, endeavoured, by mcans of thefe new dye-ftuffs, to difcover more durable and livelter colours; for though they had began, almoft at the fame time as the Italians, to apply to the art of dyeing with great zeal, and to take advantage of the troubles in the Eat, they had never been fo fortunate, notwithftanding all their exertions, as to make any great progrefs in it.

- This divifion was made in the earlieft periods in Italy as well as in France, as proved by a French ordinzace of Nov. $17,1_{3} 8_{3}$; but it had not been fo thrielly obfervas till Colbert found it nectflary to define it wore aceurately. 
At lait a Flemilh painter named Peter Kloeck, who, during his long travels in various parts of the Eaft, had learned the art of giving the moft beautiful colours to filk and woollen ftuffs, as well as that of dyeing fcarkt, which he acquired from the German inventor whom I thall mention hereafter; returned to his own country *, excited as much attention by his method as Gobelin did at Paris, foon brought dyeing into repute, and continued to practife his art till $155^{\circ}$, when he died $t$.

After that epoch this art was exercifed by the Flemings with fo much zeal, that the Netherlands afterwards fupplied not only France, but even England and Germany, with experienced dyers.

Dyeing feems to have been practifed alfo in England at a very early period, for in the 14th century Edward III. brought a great many dyers from Flanders $\ddagger$. Under Edward IV. dyers were fo numerous in London, that in the year 1472 they were eftablifhed into a particular company, which at prefent forms one of the ninety-two incorporated companies, and holds the thirteenth rank : this company has its own arms, and its hall on Dowgate-hill \&.

After the difcovery of America the new dye-ftuffs began to be ufed alfo in England; but here people were at firft fo miftruftul of them, that under queen Elizabeth dyeing with indigo was not only limited, but the ufe of logwood was entirely prohitited, and it was burnt wherever it was found $\|$. This prohibition was afterwards répeated, but it was annulled under Charles II. in 1661. I

- Beckmann's Technolgy, p. 64.

+ Mem, de l'Acad. de Berlin, i767, p. 32 .

* Rymer's Alia publica, tom. ii. p. iii. p. 68 .

$\$$ Noorthouck's New Hiftory of London, vol. ii. p. 60 .

1 The Statutes at large. Statute 23 Eliz. c. 9 ; an act for abolifining of certain teceitful ftuff ured in dyeing of cloth, \&c.

9 Statures of Charles II. 13.c. xx. Frauds and abufes in his majefty's cuftoms prevented and regulated. Under this head the following paffage occurs :-_" As it has now been found that our dyers, by diligence and dexterity, have made fuch progrefs as to be able to dye with logwood is good and durable colours as with other kinds of wood, the ufe of this wod is in Future permitted." 
But, notwithitanding the attention hitherto paid to dyeing by government, it ftill remained in a languifhing ftate till the year 1643 , when a German named Kepfler firt brought to England his new-invented method of dyeing fcarlet; and becaufe he eftablined a dye-houfe at the village of Bow, the fcarlet he dyed was called the Bow dye*. At length a Fleming named Brauer, who in 1667 went to England with his whole family, brought the dyeing of woollen there, in general, to that degree of perfection at which it has been fince maintained by the Englith + . Men of letters in England now began to turn their attention to this art, and we find a treatife on dyeing publithed in $1667 \ddagger$, which was foon followed by others of the fame kind.

As a difinction had always been made in Italy, France, and the Netherlands, between fine and common dyers, the cafe appears to have been the fame in England from the earlieft periods; fo that blue, red, and yellow, belonged exclufively to the fine dyers; but both the fine and common dyers were allowed to dye brown, fawn colour, and black $\S$.

Since the art of dyeing, as we have already feen, could not be revived in Italy, France, and the Netherlands, from its long ftate of depreffion to which it had been fubjected in the fifth century, it will not appear furprifing that the Germans, who during the middle ages paid very little attention to manufactures, fhould begin to apply later than other nations to this art, which is always an attendant of manufactures. All the beauitful, lively, and high colours, which are mentioned by the German writers of that period, were procured from the Italians, as thefe had procured them from the Greeks.

It is probable that the Germans had dyers of their own for black and brown colours, as the former was their gala colour or colour of honour, and the latter the common colour of the monks and other people, both of which required

- Anderion's Hiftory of Commerce, vol. ii. p. -7 .

+ Anderfon's Hiftory of Commerce, vol. ii. p. 132 .

\$ Willinm Petty's Apparatns to the Hiftory of the Common Pratices of Dyeing, in Sprat's Hiftory of the Royal Society of London, p. $2 \delta 4$.

Chambers's Dictionary of Arts, under the head Dyeing. 
no foreign dye-ftuffs or expenfive preparation. But this farcely deferved the name of dyeing, and extended at mott to linen or coarfe woollen ftuffs, and even to thefe the dyers could not communicate faft and durable colours.

As the number of thofe who prepared thefe colours afterwards increafed, the firft dyers were under the neceffity of forming themfelves into a company to fecure themfelves and their occupation from the encroàchment of foreigners; and this was the origin of that company known in Germany at prefent under the name of black dyers; but whether this fociety was formed under Henry 1 . in the year 925 , as the chancellor Von Ludewig afferts *, cannot be with certainty determined. With the above two colours the Germans were long fatisfied, till at length, in the I2th century, a great many artifts and manufacturers took thelter in Germany in confequence of Milan being over-run by the emperor Frederic I. and by the crufades the Germans in the Eaft became more and more acquainted with the woollen manufactories, which they afterwards brought back with them into their own country $\dagger$.

Thefe circumftances, and the encouragement given to the German navigation and 1rade with foreign nations $\ddagger$ by the

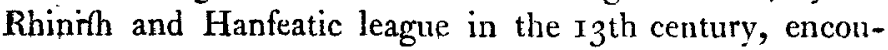
raged the Germans not only to apply with more ardour to their home manufactures, but rendered it neceffary for them to obtain better dyers and dye-ftuffs, that their manufactures might find a good fale in foreign markets. They endeavoured, therefore, to procure from Italy and the Netherlands, where the art of dyeing, as is well known, had been much cultivated, expert workmen $\S$, who, from the woad which they chiefly employed for dyeing blue and green colours, were called woad dyers and alfo clotb dyers $\|$, becaufe they dyed

* Ludewig D.ffert. de Re Bafaria Tinct. p. 1 1. only

+ See Putner's Deiffibe Reichfsefbicbte, \$107. III. p. 257.

* Ibid $\$ 118$. v. 29 r.

§ Ludewig ut fupra, p. Iz. Schreber's Abband vom IF didt, part s. §3. Zunk's Manufaclur und Hardwerks Lexicon, under the word Dyer.

II The ap, ellation woad dyer occurs in a charter of the year 1339 . Zink, therefore, is wrong when be fays that woad was not ufed till a tite period, 
only good cloths. They were called likewife Rbenifb dyers, either becaufe the Rhenifh league encouraged cloths of beautiful colours, or becaufe a great many dyers from Rhineland had fettled in other provinces of Germany.

The above league, however, endeavoured to encourage dyeing in Gernany, not only by promoting trade and procuring expert dyers, but alfo by various laws and regulations. Thus we find, befides others, an ordinance of the Hanfe towns, written at Lubec, in Latin, in the year 1418 , the fixth fection of which contains the following paffage :- "No merchant thall purchafe undyed cloth in any town and dye it in another; but the cloth thall be dyed in the place where it is bought, under the penalty of forfeiting the cloth and the dye-ftuffs *:"

After this period we find two kinds of dyers in Germany, wiz. the before-mentioned cloth, woad, or Rbenifh dyers, and the old black or ordinary dyers. The former endeavoured chiefly to improve their art by new inventions, as was the cafe in the I6th century, when a fine dyer, whom fome call Küfter, others Küffler, fome Kepfler, and the Dutch Drebel, found out, by means of a folution of tin, the art of dyeing the new fcarlet colourt. From this dyer the before-mentioned German painter, Kloeck or Glück, learned the art; and Gobelin having been taught it by the latter, it was foon made known over a great part of Europe. Befides, the Germans now began to eftablifh filk manufactories; and as filk. required a particular method of dyeing, there arofe a new kind of dyers called filk-dyers, of whom mention is made in the laws of the empire in the 16 th century $f$.

At laft dye-ftuffs, before unknown, from the newly-difcovered countries, or at leaft fuch as were rare and expenfive, and that, therefore, the black dyers, by way of ridicule, called the fine dyers woad dyers.-See Grofler Analecta Fuftor. Zittauienfium, p. iv. c. 4 p. $168 . \$ 10$. The name clotb dyer occurs frequently in the laws of the empire. For example, in thofe of the year 1577, under the head Purshasing of Woollen Cloth, \& $3 \times$. alfo 3 .

* Puitter's Reicb/grefichichte, $\$ 145$. iv. not. 10,

+ Hellor on Dycing, p. 276; Beckmann's Technology, p. 64. The antients had a fcarlet colour which they dyed with the coccum kermes.

¥ See Reicb's Abfcb. xu Regenfourg for the year 1594:

Ver. IX.

$\mathrm{R}$. 
being imported into Europe, were much employed by the German, Italian, and French dyers. By thefe productions they were enabled to prepare dyes much more beautiful and at lefs expenfe than they had ever been able by means of the dye-ftuffs before known.

As the Germans did not obtain thefe new dye-ftuffs fo early, and were not yet acquainted with the art of treating them, the Flemith and French dyers came to Germany in great numbers, and united themfelves to the German cloth and woad dyers, under the name of the art, woad, and fine dyers*.

Thus, in the middle of the I6th century, a Fleming, named John Nicolaus Schmidt, eftablifhed a houfe for fine dyeing at Gera $t$. But on this occafion the jealoufy and envy of the black dyers, who had hitherto been fecret enemies to the woad dyers, were difplayed in their full force. They not only perfecuted with all theit might the new ftrangers, but they endeavoured to make the new dye materials, which the fine dyers particularly ufed, to appear to the different princes contemptible and pernicious; efpecially as they were already difagreeable to financièrs, becaufe they leffened the confumption of indigenous productions, and efpecially of woad. The elector of Saxony $\ddagger$ and duke Erneft the Pious $\S$, therefore, not only iffued fevere prohibitions againft indigo; but it was made a fubject of difcuffion at the diet, where it was defcribed as a pernicious eating devil and corrofive dye-ftuff $\|$.

The ufe of thefe ingredients, however, had become fo prevalent, and their fuperiority to the indigenous was too evident to admit of their being entirely banithed. On the other hand, the divifion into fine and common dyers, to which the French and Dutch dyers were already accuftomed, was more firmly eftablifhed; and both kinds diftinguifhed themfelves by their greater or lefs dexterity; by the dye-ftuffs they em-

* Hence arofe, no doubs, the connection which ftiil fujoffts between the German fine dyers and the French, Engluth, and German dyers, as the black dyers cannot go beyond the boundaries of Germany.

+ Ludewig ut fupra, p. I.

$\$$ Codex Auguffeus, part i. p. 236, 1521, 1547 .

$\$$ Gothaifche Landefordnung, p. 2.

If R. Pol. O. 20 Frankf. 1577. tit. 21. \$3. 
ployed; the inftruments they ufed; their fellowipip; and, in the laft place, by the objects to which their attention was chiefly directed.

The black and common dyers, particularly in Saxony, learned the art of communicating good dyes to linen or linfey-woolfey, and affumed the title of black and fine dyers, by which they endeavoured to diftinguith themfelves from the common linen dyers, as they were then called. They were, however, eftablifhed into one company with the black and fine dyers by an ordinance of the elector of Saxony, dated May 24th 1595, and divided into three principal branches, viz. thofe of Leipfic, Drefden, and Zwickaw *; and this union chancellor Von Ludewig confiders, improperly, as the union of the art dyers with the black dyerst. Such is the ttate of dyeing at prefent in Germany, and of the eftablifhment of the dyers.

\section{S \\ XL. A Biograpbical Sketcb of Count RuMFORD. \\ OIR BENJAMIN THOMPSON, Count of Rumford, a} native of America, was born in the town of Rumford, in the province of Maffachufets. In the American war he raifed a regiment of dragoons, and fignalifed himfelf on different occafions in the fervice of the mother country. In February 1784 he received from his Majefty the honour of knighthood; and in the fame year, with his fovereign's permiffion, engaged in the fervice of his Serene Highnefs the Elector of Bavaria.

In that electorate his fervices were of the moft active and ufeful kind; for, in addition to the duties of his military profeffion, he devoted himfelf to the amelioration of the condition of the vagrant poor : a Herculean labour, of which no one can form an adequate idea without perufing the account fince publifhed by the Count, and yet managed with fo much addrefs as to conciliate the good wilhes of even the

* Schreber Befchreibung des Waidts, pare $5 . \$ 3$.

+ Ludewig ut fupra. This perhaps may have induced Von Jufti, in his Policevwiflenf6baft, vol. i. book 5. p. 20. div. 3. $55^{8} 3$. to make the ane atrerion. 